Research

\title{
Unpacking the Impact of the COVID-19 Pandemic in Zimbabwe`s Public Sector
}

\section{Sharon R. T Muzvidziwa-Chilunjika ${ }^{1},{\text { Bismark } \text { Mutizwa }^{2} \text {, Alouis Chilunjika }}^{1}$}

${ }^{1}$ Midlands State University, Department of Politics and Public Management, P.O. Box 100, Buchwa Road, Zvishavane, Zimbabwe.

${ }^{1}$ University of Zimbabwe, Political and Administrative Studies Department, P.O. Box MP 167, Mt Pleasant, Harare, Zimbabwe.

Article History

Received:

30.09.2020

Revised:

23.11.2020

Accepted:

11.12 .2020

*Corresponding Author:

Sharon R.T Muzvidziwa-

Chilunjika

Email:

srtchilu@gmail.com

This is an open access article, licensed under: $\mathrm{CC}-\mathrm{BY}-\mathrm{SA}$

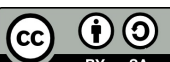

Abstract: The novel COVID-19 pandemic has ravaged the entire world and its far reaching impacts have been felt across different regions and sectors world-over. Similarly, the Zimbabwean public sector has been equally affected by this pandemic. Using a qualitative methodology the research interrogates the effects of the COVID-19 pandemic and proffers ways to deal with its impacts on the Zimbabwean public sector. Data was extensively collected from documentary sources such as books, journals, government publications etc. The study established that the Zimbabwean Health Sector (ZHS) is completely overwhelmed by the pandemic, that there is a decrease in revenue collection, poor social accountability, and corruption and that frontline employees and those working in environments that are exposed to the virus are psychologically affected. The research recommends that the government should capacitate the ZHS, revitalise industries and harnessing small to medium enterprises, embrace open Information Technologies (I.T) in parliamentary activities, strengthen the Watchdog institutions and create sustainable conducive working conditions for all.

Keywords: COVID-19, Impact, Organisational Capacity, Public Sector, Zimbabwe Health Sector. 


\section{Introduction}

Public sector institutions across the globe share a common challenge that is weak performance in the area of service provision. Despite this, the outbreak of the COVID-19, has further crippled the performance of public sector institutions as nations have been ushered into an unprecedented recession. In an effort to curtail the effects of the COVID19 pandemic, developed, developing and even resource constrained states have all implemented various measures to ensure that their public sectors do not collapse. While the degree of the impact varies, at some point all nations have had their economies on halt. Like all nations across the globe, Zimbabwe was not spared by the COVID-19 pandemic, and its impacts have manifested in varying magnitudes across the public sector. Organisational or institutional capacity has been undermined, employees have been psychologically affected, horizontal accountability has been compromised culminating in the mushrooming of corruption and revenue collection has decreased due to the on-going moratorium of key economic activities among others [1]. The health sector has been completely overwhelmed with the frontline workers being exposed to the invisible enemy as a result of inadequate personal protective equipment (PPE) and dilapidated equipment $[1,2]$. This has led to industrial action by the health workers across the nation. It is against this backdrop that the research seeks to interrogate the impact of COVID-19 on the Zimbabwean public sector. The research takes a holistic investigation of the entire public sector in a bid to present a glimpse of the effects caused by the COVID-19 pandemic and proffer recommendations on how best the pandemic can be curtailed in Zimbabwe's public sector.

\subsection{The Zimbabwean Public Sector}

The Zimbabwean Government after independence replicated the British system of administration [3]. Mutizwa [1] reinforces Chilunjika and Mutizwa's view by purporting that, "the genes of the Zimbabwean public sector are engraved in Zimbabwe's former colonial master system of administration." This can be depicted by the socialist dogmas of the late 19th and early 20th century coupled with the development concept of "the well-being of the state". The public sector emerged as custodians of state welfare and vehicles of services delivery to the mass [3]. The public sector was created as part of a philosophical coordination embedded in the efforts to do away with the exploiting class system of capitalism. Thus, the public sector was programmed to be a vehicle of affordable service delivery to the masses, to curb the inimical effects of capitalism and market failure ([1] citing Stoneman 1976:33). Similary, Zhou \& Zvoushe [4] and Chilunjika \& Mutizwa [3] stated that in both conceptual and hypothetical terms, the public sector was considered as a critical, indispensable apparatus for economic planning and development of the nation at large.

Nonetheless, Chilunjika and Mutizwa [3] postulate that:

"Despite such a portrayed glamorous picture of parastatals, at their inception across the globe they have encountered numerous predicaments emanating from maladministration, nepotism and economy of affection. Zimbabwean parastatals are not immune to these challenges as displayed by corporate governance epidemics which have caused great turbulences in the public sector."

Chilunjika and Mutizwa's narrative purports that the public sector has become a haven of corporate governance fixes, as public sector organisations have been constantly dogged by performance malaise and operational challenges. As such, with the COVID-19 pandemic, the Zimbabwean public sector has been further exposed to numerous morasses such as corruption, decrease in revenue generation and collection, poor social horizontal accountability, inadequate PPE and dilapidated infrastructure with hospitals being completely overwhelmed and employees being psychologically affected [1]. It is in line with this, the research examines the how COVID-19 has affected the Zimbabwean public sector.

\subsection{Rationale of the Study}

The study scrutinises the impact of COVID-19 on the Zimbabwean public sector. The study is not only timely but rather worthwhile and relevant as researches pertaining to the impact of COVID-19 on the Zimbabwean public sector are still few and nascent. The study is imperative as it interrogates 
events as they unfold and provide an exploratory, explanatory and descriptive research that stimulates further studies on how COVID-19 has affected the Zimbabwean public sector. The findings of the study will play a pivotal role in informing public administrators and the policy making machinery on the protocols to adopt and implement in dealing with future pandemics.

\section{Literature Review}

\subsection{Global Economic Impact of COVID-19}

COVID-19's impact on the global economic arena has remained highly fluid. Developing and developed states have all been taken aback by the devastating impacts of COVID-19 on the global economy $[5,6]$. The once celebrated globalisation and technological advancement has done little to redeem or recalibrate global economies to circumvent COVID-19. Uncertainties concerning the depth and length of the health induced crisis have increased the degree of alertness of risk and instability, volatility, unpredictability in financial markets as well as corporate decision-making.

Congressional Research Services Report [7] noted that:

"the pandemic is undesirably affecting universal economic growth beyond anything witnessed in almost a century. Projections point out that the virus could dwindle economic growth by $3.0 \%$ to $6.0 \%$ in 2020 , with a partial recovery in 2021 , supposing there is not a second wave of infections. The economic fallout from the virus increases the threats of a worldwide economic recession with levels of unemployment not experienced since the Great Depression of the 1930s."

Similarly, the Africa Union [8] reinforces the above narrative by articulating that:

The European Union, the United States and Japan account for half of the world's GDP. These economies are based on trade, services and industries. However, measures to halt the pandemic have forced them to close their borders and drastically reduce economic activities; which will lead to recession in some of these developed economies. The Chinese economy accounts for about 16\% of the global GDP and it is the largest trading partner of most African countries and the rest of the world. The OECD forecasts a decline in economic growth rates for these major economies as follows: China $4.9 \%$ instead of $5.7 \%$, Europe $0.8 \%$ instead of $1.1 \%$, the rest of the world $2.4 \%$ instead $2.9 \%$, with world GDP falling by 0.412 from the first quarter of 2020. UNCTAD forecasts downward pressure on foreign direct investment from $-5 \%$ to $-15 \%$. The International Monetary Fund has announced on the 23 March 2020 that investors have withdrawn US\$ 83 billion from emerging markets since the start of the crisis.

This implies that the pandemic has negatively affected economic growth in different countries across the globe. The International Monetary Fund (IMF) [9] and Mutizwa [10] argued that the pandemic has robbed the globe of the much needed human capital. Congressional Research Services Report [7], SADC [11] and Pineda \& Musacchio [12] reinforce the above view by noting that, the lost human capital impacts negatively on global economic growth coupled with the disruption of careers, social unrest and a rise in poverty and destitution. The Economic Commission for Latin America and the Caribbean (ECLAC) [13] postulates that the pandemic has also affected trade growth in Latin America and the Caribbean region, economies are going down with little hope of them recovering in 2020. According to the Congressional Research Services Report [7], Pineda \& Musacchio [12] depending on the length, extent and depth of the pandemic, global trade might "fall by $13 \%$ to $32 \%$ ", with developing states for example those in the Latin America and the Caribbean likely to be affected the most.

National imposed lockdowns, the closure of boarders, airspaces, industries and schools as ways of curbing COVID-19 also had devastating effects on trade, tourism and oil related industries [10]. Equally, Ozili [5] note that the lockdown measures by various nations lead to in the reduction of oil, coal and aviation fuel demand on the global market. The implemented measures to curtail the virus come with economic ramifications as evidenced by the loss of incomes due to reduction in labour task 
forces, absenteeism increase at workplace culminating in low productivity globally.

\subsection{Country Experiences}

This section presents a preview of other nations' experiences with COVID-19. Literature from developing and developed nations is presented to unpack the impact of the COVID19 pandemic in different nations.

\subsubsection{The Effects of COVID-19 in Developed Nations}

\section{Italy}

The effects of the COVID-19 pandemic has left the globe facing one of its darkest hours in contemporary history. The Italian economy has suffered massively despite Italy being known to have a viable public sector with a functional health system. According to Mutizwa [10] the Italian public health system was "overwhelmed" by the pandemic which caused panic across Europe and in the developing nations. The military had to step in to help the police, doctors, nurses and transportation services as the entire public sector was down [14]. Local authorities were unable to render their services as they could not handle the demand caused by the increase in contamination rate leading to loss of many lives. The Italian Prime Minister had to declare government incapacitation to handle the disaster and called upon the European Union to intervene. This was because organisational capacity was undermined by the huge number of deaths which robbed the nation of the much needed human capital to respond swiftly. Moreover, statistics indicated that industrial production almost halved in April 2020, and due to the several fiscal support packages by governments to cushion individuals and firms, the Italian public debt is expected to rise over from 134.8\% to $160 \%$ of the GDP in 2020 .

\section{Malaysia}

The COVID-19's effects on the Malaysian public sector were unfavourable and malevolent just like in Italy. Malaysia's tourism and trade sector which are the nerve-centre for fiscal generation were seriously affected thus robbing the nation of the much needed revenue to support government projects. Shakeel [15] noted that the Visit Malaysia 2020 (VM2020) campaign which had targeted approximately $\$ 30$ million in revenue inflows was cancelled leaving the nation with unbearable expenses that had been accumulated in preparation for the VM2020. This was a major drawback not only in revenue collection but in development and growth as various sectors would have benefited from tourism. Sectors that would have benefited include hotel industries, transport industry, fuel industry as well as the health industries. Shakeel [15] argued that, the impact of the COVID-19 pandemic was of concern as the tourism industry of Malaysia is a major source of foreign exchange in national economy. The tourism contributes to more than $50 \%$ of export trade-in service, with approximately 27 million tourist visits in Malaysia annually.

The VM2020 campaign aimed at generating up to RM 100 billion. Nonetheless, with COVID-19 and the fact that $60 \%$ of the tourists in the last past five years were from China - saw the campaign being suspended [15]. Malaysia anticipates a 50\% decrease in visits thus signifying a great loss in revenue generation [16]. The central bank of Malaysia, Bank Negara Malaysia postulated that the financial development and growth has been hibernated by the pandemic resulting in trade and production declining by $3.0 \%$. Local authorities' fiscal space and service delivery has been undermined, with local hospitals and clinics failing to cope up with the demands imposed by the pandemic.

The Ministry of Health $(\mathrm{MoH})$ was also hit hard as the spread of the virus intensified which led to the Director General of the $\mathrm{MoH}$ to invite the intervention of private hospitals, university hospitals as well as Ministry of Defence hospitals [17]. The police and military also worked overtime trying to enforce the Movement Control Order (MCO) which was implemented to curtail the spread and the mortality rates. To curb the pandemic and its socio-economic effects, a stimulus package of RM 20 billion was released in February. This was further supported by the 250 billion stimulus package which was meant to rejuvenate the public sector and other private entities that were incurring loss due to the pandemic [18].

The stimulus package was also used to revitalise local authority fiscal space and service delivery. 
A provisional hospital with 604 beds was constructed and this helped in job creation thereby addressing some of the socio-economic quandaries.

\section{United Kingdom, France and Germany}

Although the impact of the pandemic has been severe on many global economies, the impact differs according to the nations' preparedness, capacity and development. The United Kingdom (UK), France and Germany are some of the countries whose public sector remained vigorously functional. This was necessitated by the adaptive, robust management and operational services, leadership and resource capacity of their public sectors. All disaster management protocols were activated, social safety nets were availed and businesses were giving loans to their employees to circumvent the depression caused by the virus. Congressional Research Service [7] noted that the IMF highlighted that the impact of the COVID-19 pandemic on the UK, France and Germany might have slowed growth but was not a fatal blow to institutional and organisational capacity, hence they responded swiftly to the virus. The African Union [8] stated that all this was necessitated by the fact that France announced 334 billion Euro as response to COVID-19, Germany 13.38 while England reduced interest from $0.75 \%$ to $0.25 \%$ and 37 billion as a cushion to the COVID-19 pandemic.

\section{China}

The story of China deserves attention, the same way it attracted condemnation for the outbreak of the virus. The way China handled the virus leaves many questions answered from virologists, organisational specialists, intelligence officers, engineers and doctors. It makes one to question whether the virus that caught the world by surprise caught them aware and prepared? Nonetheless, that is not the centre of the argument, the purpose of this narrative is to bring to light how swift China was in curtailing the virus without incurring many economic losses. The way China handled, managed and contained the epidemic projected exceptional preparedness and adaptive capacity despite being the hotspot and epicentre of the virus. Holland \& Lin [19] further articulated that the adaptive capacity of China's public sector and swift coordination deserves praise, as vigorous measures were implemented with Wuhan being locked down for 77 days. The Africa Union [8] notes that China had to lower reserves and free up more than $\$ 70.6$ billion to boost the economy and announced aid of 154 billion dollars. Similarly, Holland \& Lin [19] noted that a hospital designated for COVID-19 was constructed within two weeks and employees were recruited to reinforce human capital. An examination of China's responses to the virus and how economic activities in other region were not interrupted shows exceptional leadership, management and operations, services and resources capacity.

\subsubsection{The Effects of COVID-19 in Developing Nations}

\section{Kenya}

The pandemic had devastating effects on the Kenyan public sector. A decline in revenue collection was witnessed while it's GDP which was at 5.7\% prior to the COVID-19 pandemic decreased to $1 \%$. The inflation rate which was at $5.9 \%$ increased to $6.5 \%$ [20]. The Kenyan flower sector which contributed immensely to growth and development in Kenya was said to be losing 250 million Kenyan Shilling per day with a 60 billion estimated loss by the end of the year. This culminated in employee lay off as organisations struggle to survive in the volatility business environment induced by COVID-19. Approximately 40000 permanent employees were put on an unpaid leave while about 30000 temporary employees lost their jobs. The tourism sector which accounts for the $8.5 \%$ employment in the country and approximately 1.6 million revenue generation has been affected by the global lockdown drive [20,21]. Government hospitals were completely overwhelmed due to dilapidating equipment as well as under stuffed. Local authorities were failing to offer viable service delivery as their fiscal space continued to shrink [22]. The Kenya Revenue Authority also registered a revenue decline thereby failing to reach the expected target and negatively affect public finance management and the country`s ability to service its debt. 


\section{Ethiopia}

The Ethiopian case is not different from that of other African nations. The Ethiopian economy is at the mercy of the loathsome impact of the pandemic. Economic development and growth has been interrupted, resources that were meant to further developmental projects have been redirected to curtail the "invisible enemy" [10]. Since then, a decline has been recorded in the Ethiopian economy. Prior to the pandemic, the IMF had projected a $6.2 \%$ growth; during the pandemic the IMF had to reevaluate and a decline to $3.2 \%$ was registered [20]. Inflation rate rose to $15.4 \%$ due to the imposed international lock down. The re-directing of resources to save lives has also seen the inflation rate soaring to $20.6 \%$ [20]. As a result, the public sector has been affected the most, with the tourism sector registering a decline in economic activities. The tourism sector employees about $8.3 \%$ which is around 2.2 million jobs. This gravely affected the Ethiopian Tourism Organisation as it has reported struggling to raise its workers' salaries. The once celebrate African Air giant Ethiopian Airlines also lost about USD 550 million between January and mid-April [20].

Ethiopian airways wholly owned by the government plays a major role in the country development and fiscus. To make matters worse the IMF has projected a decline of $18.8 \%$ on government tax revenue and $7.7 \%$ decrease of non-tax revenue. The number of those who are living below the poverty datum line is also expected to rise from 26 million people to 31 million people by 2021 [20]. The entire public sector is in dismay, incapacitation has become the order of the day with government expenditure becoming unbearable [20]. To this end, the Ethiopian Job Creation Commission has projected that approximately 90000 jobs are likely to be lost in both the public and private sector.

\section{Tanzania}

Like in other developing nations, the impact of the COVID-19 pandemic on the Tanzanian economy and the public sector hampered growth and development. Prior to the pandemic Tanzanian`s GDP was estimated to rise by 5.3\%; nonetheless, with the pandemic Tanzania `s GDP is expected to decrease to $2 \%$ [7]. The agricultural sector is at the centre of growth and development in Tanzania as it employs about $67 \%$ of the total workforce, and contributes about $27 \%$ to the GDP [20]. However, this is likely to change, as the major export destinations of Tanzania`s tobacco, coffee and fish are in recession hence a decline in the demand scale leading to revenue loss [22]. The World Health Organisation's social distancing regulations have also interrupted the mining sector which is very crucial to the Tanzanian economy; this has led to the closure of mines and the laying off of temporary employees and unpaid leave for permanent employees. A majority of key public institutions in low and medium income countries are thus are operating below optimum efficiency. Unlike in developed nations, these developing nations do not have sufficient revenue to implement robust social nets that supports growth and development during such global catastrophes.

\subsection{Difference between Developed and Developing Nations}

The pandemic had different impacts in developed and developing nations owing it to a myriad of reasons namely national preparedness capacity, adaptive capacity, resource and management capacity. Developed nations have resilient disaster management frameworks that are viable and effective in addressing national disasters. On the contrary the majority of developing nations are in debt distress as such, they do not have resources to set up robust disaster management structures, which has led to dramatic effects on the wellbeing of communities and economies. Most public institutions in these nations responsible for service delivery have been crippled, translating to an increase in severe poverty, reduced access to basic services such as clean water, food, healthcare and education [23]. In most cases the revenue they generate is directed towards debt service or is similarly embezzled in corrupt deals, while in developed nations revenue is usually directed towards social services, disaster management and national development.

\section{Methodological Framework}

The research benefited immensely from documentary review. Books, journals, newspaper articles, Government publications among other written sources were also extensively reviewed in helping to unpack the impact of the COVID19 pandemic on Zimbabwe's public sector. The study took a holistic approach in covering almost the entire public sector to generate a comprehensive research. 


\section{Discussion}

\subsection{The Zimbabwean Health Sector (ZHS) has been Completely Overwhelmed}

The study established that, the ZHS is completely overwhelmed by the pandemic. This is because the ZHS adaptive capacity has been constantly found wanting due to a number of factors which encompass the lack of human capital, financial capital, service and limited management operations capacity. The COVID-19 pandemic pounced heavily on an already debilitated, incapacitated and compromised sector. The ZHS was found unprepared with no single ventilator and this led to the death of the first reported COVID19 patient at Wilkins Hospital in Harare [10, 24]. Renovations, purchases and donations of ventilators, boreholes and solar systems only took place after the death of that particular patient [25]. The above narrative exposes ZHS' unpreparedness which therefore exposes the leadership and management operations capacity [10]. The Harare City Council Health Service Director noted that, after renovations Wilkins had the capacity to accommodate 60 active COVID-19 patients with 10 in the Intensive Care Unit (ICU) [10]. To this, Mutizwa [10] argue that, though the renovations are welcome, Zimbabwe has an estimated population of 14.833 .632 and if hit hard by the virus those 60 beds cannot be a call for celebration, but rather a wakeup call on what ought to be done by the state.

In addition to the above, as of 20 July 2020, the Zvishavane District Hospital was shut down after twenty-five of its workers tested positive to the virus [26]. Accordingly, the health care workers were reportedly having inadequate PPEs and them being at the forefront in this war, they were highly exposed to the pandemic. The closure of the hospital had grave ramifications as it is the only government hospital in the entire district. Furthermore, citing poor salaries, dangerous working environment and lack of medical supplies, the Zimbabwean doctors and nurses embarked on a series of indefinite strikes which pushed the country's case load from 62 to 463 . The failure by the government to move swiftly in curtailing these challenges in the health sector are seen as catalysts for fuelling the health crisis in the country.

\subsection{Decrease in Revenue Collection}

The Zimbabwe National Roads Administration (ZINARA) has also been hit hard by the pandemic. ZINARA is sanctioned by the state to collect tollgate tariffs across the country [27]. For Chideme cited in Chilunjika [18] the money collected from tollgates is used to renovate roads and support all projects that are related to road construction without straining the national purse. Therefore, with the current lockdown, movements from city to city have been prohibited and buses have been parked. This means that the number of vehicles on the road has decreased tremendously imparting negatively on domestic revenue mobilisation. If one is to go by Chideme and Chilunjika's narrative, this means that all road projects have also been suspended due to the strict lockdown restrictions and the subsequent dwindling revenue inflows as a result of reduced vehicular volumes on the highways. The research also discovered that, ZINARA's organisational capacity is also under threat as it pays its employees from the monies they collect from tollgates. Thus the longer the pandemic is going to remain unaddressed, the more their employees' psychological well-being is threatened as a result of delays in their salaries.

The operations of the Zimbabwe Revenue Authority (ZIMRA) have been equally affected by the pandemic. ZIMRA generates much of its revenue from national and international customers. According to Zhou \& Chilunjika [27] ZIMRA is mandated to collect customs duty on all boarders as well as tax from various corporates across the nation. The current lockdown across the globe has culminated in the closure of boarders and industries. Accordingly the closure of all border posts implied a sharp decline in the revenues that were to be generated from import duties, excise duties, value added taxes (VAT) among other tax heads. According to the Zimbabwe Independent, Zimbabwe is likely to lose ZW\$ 57.8 billion in 2020 due to the pandemic. This will have a devastating impact on the national purse as that this revenue is supposed to help in financing various projects across the Zimbabwean public sector.

In addition, local authorities have also been affected heavily. The lock down has significantly affected their revenue generation capacity and ability. Local authorities generate their revenues from fees they charge citizens for parking and vending. This money together with some from service delivery fees is used to pay the salaries of their employees, finance service delivery and other council expenditures. The longer it is going to take whilst the country is locked down, the higher the chances that the local authorities will fail to provide basic services and pay their employees on time. A good 
example is that of Chiredzi Town Council (CTC) whose employees are owed up to three months salaries. Already there was a backlog in the council employees' salaries way before the lockdown hence the current lockdown has exacerbated the situation. As such, the families of the employees at these local authorities are exposed to extreme poverty.

\subsection{Poor Social Accountability}

The study learnt that during the lockdown the Government of Zimbabwe introduced a moratorium which exempted some activities in the economy. This has had a negative impact in promoting social accountability which is a yardstick of a viable public sector in any nation. The COVID-19 regulations have hindered the capacity of the parliament in undertaking its duty as the carrier of masses' wishes and voices as the strict lockdown requirements forbid people from gathering and meeting physically. There is a correlation between good governance and robust parliamentary oversight. According to the Audit Office Act and Public Finance Management, the parliament as a supervisory body has the responsibility to oversee the performance of all parastatals and government departments. To this end, that role has been greatly affected as inclusive and horizontal accountability has been completely derailed due to the lockdown.

Additionally, during the COVID 19 imposed lockdown the Government of Zimbabwe has embarked on a constitutional amendment consultation process. This was interpreted as the Government's deceitful way of smuggling unconstitutional practices into the democratically crafted constitution. Questions are then raised on the Government's hasty move to fast track this process during the COVID19 induced lockdown when the critical players are not being allowed to congregate. This connotes that there is a shadow democratic crisis which is being used by the Government to short-circuit processes [18]. For instance, if the constitutional amendment is to pass then Zimbabwe will have a compromised judiciary as the president would have the Prosecutor General at his own discretion without parliamentary vetting. Another issue to note is the need to pass a law that allows the state to borrow without parliamentary approval (Zimbabwe Coalition on Debt and Development.

All this is being necessitated by the pandemic which has divided people's attention and enforced the suspension of parliamentary activities after two Members of Parliament and a driver tested positive to the virus. All parliamentary committees have suspended their oversight, monitoring and evaluation roles [18]. It is not only humanity that is under threat from the invisible enemy but rather public sector accountability, transparency and integrity. Equally important to note is the fact that there is schism in the corridors of the government as public officials have conflicting views concerning the proposed constitutional amendments.

\subsection{Corruption}

The Zimbabwean public sector has always been a fecund ground for corruption and rent-seeking (Chilunjika 2018). The pandemic has open portals of "economies of affection" and sophisticated networks of corruption to defraud the state and burden the public with taxation. The public sector has been gravely affected as intended strategies are derailed, resulting in unrealised strategies [3]. Thus, all the strategies that the ZHS has had in combating the virus and hope that the Zimbabwean people had, that the donations and funds will be used appropriately have been crushed. The impact of such corrupt activities culminated in the incapacitation of the health sector with a series of strikes from nurses and doctors [10].

The Drax scandal was the last nail on the coffin and also a testimony of how deep corruption runs in state institutions. The impact of COVID-19 on the Zimbabwean public sector is that it led to the birth of a shadow pandemic in the ZHS where funds were misused depriving the citizens basic healthcare [10]. The British Broadcasting Cooperation (BBC) (2020) articulated that approximately US \$20 million was looted in a tender scandal. The Minister of Health is allegedly to have directed that Drax be awarded the tender to supply COVID-19 equipment, medicines and face masks. This was in direct violation of Public Procurement and Disposal of Public Assets Act as Drax's ability to deliver was not assessed and also the tender bidding process was not followed. What is more worrying about this so-called "Covidgate" scandal is that, the Zimbabwe Anti-Corruption Commission (ZACC) did not arrest the then minister when the scandal was brought to light on social media by citizens. It took the brave fight of journalists and citizens posting on Twitter and Facebook day in day out signing petitions for the minister to be arrested. After almost a month of noise on social media the then minister was arrested and relived of his duties. 


\subsection{The Psychological Well-being of Employees}

The growth and sustainability of every organisation is attached to its human and financial capital. The welfare and well-being of employees play a vital role in the attainment of an organisation's competitive advantage [1]. Organisational capacity which is a prerequisite for the attainment of organisational optimum efficiency is interlocked with robust human capital [1]. Schaufeli \& Bakker [29] and Çankır \& Şahin [30] articulated that, the psychological well-being of employees is imperative for work engagement which is regarded as "a mental state in which the personnel works vividly, focused, and with feelings of commitment." Çankır \& Şahin [30] and Sonnentag \& Freese [31] noted that work engagement is three dimensional, encompassing dedication, vigor and absorption. In line with the above narrative, front line employees in the Zimbabwean public sector have been demoralised as they are emotionally affected due to the unavailability of adequate protective equipment. Employees from ZINARA particularly toll collectors, immigration and ZIMRA officers at border posts, as well as the police officers on roadblocks have been psychologically affected by the unavailability of protective clothes and this negatively impact on their work engagement and job performance as they fear for their dear lives as a result of the novel coronavirus [18].

The study also established that, ZIMRA's Chiredzi and Bulawayo Branches were closed after one employee succumbed to COVID-19 [32]. The employee in question was a senior ZIMRA official stationed in Bulawayo and had visited Chiredzi branch on official duty upon returning to Bulawayo the employee in question then passed away [32]. The announcement of the news was terrifying and horrific to the Chiredzi and Bulawayo employees who had interacted with him. The employees in the public sector accused the government, their employer for failing to create a conducive environment for them to work as evidenced by doctors and nurses [10].

In addition, health workers also share the same sentiments with other employees across the public sector as they narrate that their agony is far worse than any another sector [1]. This is because they are at the core of the pandemic which has threatened their psychological well-being. Rich et al [33] and Telef [34] are of the view that, it is the sole responsibility of the employer to safeguard the well-being of his employees, failure to do so will culminate in under performance. This is reflected by the Zimbabwean public sector whose performance is in decrepit [3]. There is a correlation between job performance and psychological well-being of employees and the balance between the two should not be upset if the organisation is to attain competitive advantage [29, 30, 35, 36].

\section{Conclusion}

The COVID-19 pandemic has adversely affected the Zimbabwean public sector. As such, the matrix and complexity of the impact should never be underestimated. The study discovered that not only did the pandemic undermined organisational capacity of various public sector institutions, it has led to a decrease in revenue collection, overwhelming of the ZHS, interrupted robust social accountability that facilitates horizontal accountability leading to the mushrooming of corruption. All these facts are interlinked and the current pandemic is the common denominator.

\section{Recommendation}

After unpacking the severity of the COVID 19 pandemic on the performance of the Zimbabwean public sector, the study therefore made some recommendations. These recommendations are meant to enhance the Zimbabwe's public sector's adaptive capacity and preparedness in dealing with this current pandemic.

1. Capacitation of the ZHS

The study recommends that the government should capacitate the ZHS. This can be done by constantly renovating hospitals and refurbishment of dilapidating equipment. Renovations and refurbishment coupled with the availability of personal protective equipment will enable ZHS staff to undertake their duties expeditiously. In addition to this the government should embrace and invest more on digital solutions in health such as $\mathrm{m}$-health, telemedicine, big data stems as they have demonstrated the potential to manage health care crisis. Digital solutions in health are being credited for minimizing the spread of the virus, assisting in the treatment of infected individuals, tracking the travel record of those infected and gathering data needed for sound and coordinated governance between continents. 
2. Revitalisation of industries and harnessing Small to Medium Enterprises

The revitalisation of industries and harnessing of small to medium enterprises will lead to the growth of domestic production which plays a significant role in countering exports which have been affected by the closure of border posts. This will lead to a paradigmatic shift in the reliance of international revenue collection to domestic revenue collection. Thereby increasing the government revenue base which is strategic in strengthening government's resilience against epidemics and pandemics

3. Embracing open Information Technology (I.T) In Parliamentary Activities

The study recommends the use of I.T in the day-to-day running of the parliament. The usage of interactive platforms like Zoom, Google Meet among others can be explored in cases where physical contact should at all cost be avoided. In this vein, there is need to rejuvenate parliament's awareness capacity to generate great public participation through virtual spaces.

4. Strengthening Watch dog Institutions

Empowering watchdog institutions will help curb corruption and rent-seeking activities. Thus government should give all watchdog institutions sanctioning and prosecuting authority. Prosecution and convicting of corrupt public officials will serve as lessons for those willing to engage in corruption.

5. Creating Sustainable Conducive Working Conditions

Government should create sustainable conducive working environments that facilitate growth and development as well as the psychological well-being of its employees. In this regard, inclusive social safety nets, insurance, good remuneration and adequate protective clothes should be availed for all those who are working on exposed environments during this pandemic and beyond.

\section{References}

[1] B. Mutizwa, "An Investigation into Organisational Capacity for National Disaster Management in Zimbabwe: The Case of the Civil Protection Unit 2000-2019". Zimbabwe: University of Zimbabwe, 2020.

[2] N. Chingono, "Zimbabwe doctors and nurses down tools over lack of protective coronavirus gear," CNN, March 25, 2020.

[3] A. Chilunjika, and B. Mutizwa, "Exploring factors militating against the performance of parastatals in Zimbabwe: the case of the national railways of Zimbabwe from 2008 to 2016," Journal of Public Administration and Development Alternatives (JPADA), vol. 4, no. 2, pp. 4160, 2019.

[4] G. Zhou, and H. Zvoushe, "Public Policy Making in Zimbabwe: A Three Decade Perspective," International Journal of Humanities and Social Science, vol. 2, no. 8, pp. 212-222, 2012.

[5] P. K. Ozili, "COVID-19 in Africa: socioeconomic impact, policy response and opportunities," International Journal of Sociology and Social Policy, 2020.

[6] M. Chinazzi, J. T Davis, and M. Ajelli, "The effect of travel restrictions on the spread of the 2019 novel coronavirus (COVID 19) outbreak," Science, vol. 368, no. 6489, pp. 395-400, 2020.

[7] Congressional Research Services. Global Economic Effects of COVID-19. Washington DC: Congress Research Services, 2020.

[8] African Union. Impact of Coronavirus (COVID-19) on the African Economy, Africa: Addis Ababa, 2020.

[9] IMF. World Economic Outlook Update, Washington, D.C IMF publishing, 2020.

[10] B. Mutizwa, "COVID-19 a Global Nightmare: Revamping the Zimbabwean Health Sector (ZHS) for Future Epidemic and Pandemic Management," Journal of African Problems \& Solutions (JAPS), vol. 2, no. 1, pp. 59 -73, 2020.

[11] SADC. Impact of COVID-19 on SADC Economy, Gaborone SADC, 2020. 
[12] E. Pineda, and A. Musacchio, "Solving the state-owned enterprises puzzle in Latin America and the Caribbean," [Online]. Available: https://blogs.iadb.org/gestionfiscal/en/solving-the-stateowned-enterprises-puzzle-in-latin-america-and-the-caribbean.[Accessed: February 2, 2020].

[13] ECLAC. "Latin America and the Caribbean and the COVID-19 pandemic: economic and social effects", COVID-19 Special Report, no. 1, 3 April. Santiago: ECLAC Publishing, 2020.

[14] G. M. Pedersen, and M. Meneghini, "Quantifying undetected COVID-19 cases and effects of containment measures in Italy." 2020. [Online]. Available: https://www.researchgate.net/ publication/339915690. [Accessed: February 2, 2020].

[15] S. Shakeel, A. Hassali, and A. Naqvi, "Health and economic impact of COVID-19: mapping the consequences of a pandemic in Malaysia," Malays J Med Sci. vol. 27, no. 2, pp. 159-164, 2020.

[16] Malaysian Rating Corporation Berhad. The Malaysian economy: impact of the Coronavirus outbreak, 2020. [Online]. Available: http://Marc.com.my/index.php/marc-news/1177 themalaysianeconomy-impact-ofthecoronavirus-outbreak . [Accessed: March 21, 2020].

[17] Bernama. Government sets up Economic Action Council to address economic woes. Prime Minister's Office of Malaysia, 2020. [Online]. Available: https://www.pmo.govmy /2020/03/ government-sets-up-economic-action-council-to-address-economic-woes/ [Accessed: February 25, 2020].

[18] Parliament suspends all activities because of Coronavirus. News24.com, [Online]. Available: https://zimbabwe. shfaqna.com. [Accessed: September 24, 2020].

[19] O. Holland and A. Lin, "How to design a hospital that's built in days, by someone who's done it before," [Online]. Available: https://edition.cnn.com/2020/20/02/07/asia/wuhan-coronavirushospital-design-intlhnk/index.html [Accessed: September 24, 2020].

[20] Deloitte, "Economic impact of the COVID-19 pandemic on East African economies", 2020.

[21] Economist Intelligence Unit - Kenya Country Report, April 2020.

[22] United Nations, World Economic Situation and Prospects, 2020.

[23] R. Chikohomero, "Zimbabwe to change its Constitution under the cover of COVID 19," International Institute for Security Studies, 2020.

[24] S. Nyoka, Coronavirus: Zimbabwean broadcaster Zororo Makamba died "alone and scared". 2020, [Online]. Available: www.bbc.co.uk/news/world-africa-52061697. [Accessed: September 24, 2020].

[25] VantuNews, Corona Virus in Zimbabwe, 8 March 2020, [Online]. Available: https:// vantunews.com. [Accessed: September 24, 2020].

[26] F. Mupanedemo, and P. Chipunza, "Hospital suspends ops after 25 test positive," The Herald, 2020.

[27] G. Zhou and A. Chilunjika, "Mobilising Domestic Revenue through Toll Gate System in Zimbabwe," International Journal of Business and Social Sciences, vol. 4, no. 3, pp. 188-204, 2013.

[28] A. Chilunjika, "From corporate mess to corporate hygiene: Dealing with corruption in Zimbabwe's public sector," Journal of Public Administration and Development Alternatives (JADA), vol. 3, no. 2, pp. 52-72, 2018.

[29] W. B Schaufeli and A. B. Bakker, "Utrecht work engagement scale: Preliminary manual. Occupational Health Psychology Unit," Utrecht University, Utrecht, 2003.

[30] B. Çankır and S.Şahin, "Psychological well-being and job performance: the mediating role of work engagement," Journal of Social Sciences Institute, vol. 11, no. 3, pp. 2549-2560, 2018.

[31] S. Sonnentag and M. Frese, Performance Concepts and Performance Theory. In S. Sonnentag (Ed.) Psychological Management of Individual Performance. United States: John Wiley and Sons, Ltd, 2002.

[32] G. Mafirakureva and R. Mphisa, COVID-19: ZIMRA closes Byo, Chiredzi Offices. Newsday 10 July, 2020.

[33] B. L Rich, J. A Lepine and E. R. Crawford, "Job engagement: Antecedents and effects on job performance.” Academy of Management Journal, vol. 53, no. 3, pp. 617-625, 2010.

[34] B. B. Telef, Psikolojik iyi oluş ölçeği: Türkçeye uyarlama, geçerlik ve güvenirlik çalışması. Hacettepe Üniversitesi Ĕgitim Fakültesi Dergisi, vol. 28, no. 3, 2013. 
[35] U. E Hallberg, G. Johansson, W. B. Schaufeli, Type a behavior and work situation: Associations with burnout and work engagement. Scandinavian Journal of Psychology, vol. 48, pp. 135-14, 2007.

[36] E. L. Deci, and R. M. Ryan, Self-determination theory: A macrotheory of human motivation, development, and health. Canadian Psychology, vol. 49, no. 3, pp. 182, 2008. 